\title{
Existence and Prevention of Social Exclusion of Re- ligious University Students due to Stereotyping
}

\section{Obstoj in preprečevanje družbenega izključevanja vernih študentov zaradi stereotipizacije}

Abstract. Man is born into a tangle of standard processes and behaviour patterns created and modified over time. Through gradual socialization, he acquires the attributes of his own culture and gets acquainted with the admissible modus operandi for the social group he is a member of; he also deepens these principles and confronts them with the experiences of others. Stereotyping is a process that represents the initial classification of phenomena and people, which it categorizes into groups and assigns them positive or negative characteristics. Stereotypes form the ideas that people have about themselves and ,their' group with which they identify and are aimed at members of other groups with which they do not identify. Negative stereotypes about other people arise from pursuing one's own positive social identity and positive self-presentation. Stereotyping of believers occurs precisely because of perceived differences between ,we' and ,them' (for example, in attitudes and values, possibly in ,religious' practice). Stereotypes are often the unconscious ,beginning' of a range of known intolerant attitudes; they can lead to racism, anti-Semitism, ethnic discrimination, and other forms of intolerance. According to the experts, no nation has innate attitudes to hate, as they cannot be inherited in a biological-psychological sense. Intolerance is acquired, often to justify negative attitudes and behaviours. Using the qualitative method of guided group interviews (the so-called focus group), we examine the existence of stereotypes in university students towards their religious classmates. We consider the potential of social exclusion of young believers due to stereotypes and present current measures in prevention.

Key words: stereotype, social exclusion, social identity, adolescents, controlled interview 
Povæetek: Človek je z rojstvom postavljen v mrežo skupnih procesov in vedenjskih vzorcev, ki nastajajo in se spreminjajo skozi čas. Skozi postopno socializacijo prevzame značilnosti svoje kulture in spozna dovoljeni modus operandi družbene skupine, ki ji pripada; ta načela tudi poglobi in jih primerja z izkušnjami drugih. Stereotipizacija je proces, ki pomeni začetno razvrščanje pojavov in ljudi, vse pa nato kategorizira v skupine in jim pripiše pozitivne ali negativne lastnosti. Stereotipi oblikujejo predstave, ki jih imajo ljudje o sebi in o "svoji« skupini, s katero se identificirajo; usmerjeni so k članom drugih skupin, s katerimi se ne identificirajo. Negativni stereotipi o drugih ljudeh nastopijo z namenom krepitve svoje pozitivne identitete in pozitivnega vrednotenja samega sebe. Stereotipizacija vernikov se rodi prav zaradi prepoznanih razlik med ,nami' in ,njimi' (npr. v načinu vedenja in pri vrednotah, morda tudi pri ,religiozni‘ praksi). Stereotipi pogosto pomenijo nezavedni ,začetek' vrste znanih nestrpnih drž; vodijo lahko k rasizmu, antisemitizmu, etnični diskriminaciji in k drugim oblikam nestrpnosti. V skladu z ugotovitvami strokovnjakov ne obstaja narod, ki bi imel prirojeno sovraštvo, saj se to ne more dedovati v biološko-psihološkem smislu. Nestrpnost je naučena, pogosto zato, da bi z njo upravičevali negativno razpoloženje in vedenje. Na podlagi kvalitativne metode skupinsko vodenih intervjujev (fokusna skupina) preučujemo obstoj stereotipov med univerzitetnimi študenti v razmerju do njihovih vernih sošolcev. Obravnavamo potencial družbenega izključevanja mladih vernikov zaradi stereotipov in predstavimo aktualne ukrepe na področju preprečevanja takšnih fenomenov.

Ključne besede: stereotip, družbeno izključevanje, družbena identiteta, adolescenti, kontrolirani intervju

\section{Introduction}

Religious pluralism in European countries has not achieved the expected weakening of faith. On the contrary, it turned out that a more significant number of religious alternatives leads to an overall increase in religiosity and market competition. The individual has more choice, which increases his ,consumption' (religiosity) and, in Wohlrab's words, his interest in stricter (i.e., more fundamentalist) religious practice (Wohlrab-Sahr [n.d.]). After the fall of communist totalitarianism in 1989, Slovakia was no exception. At the last census in 2011, $75 \%$ of the state's population declared their affiliation with churches and religious societies registered in the Slovak Republic. There are currently 18 registered churches and religious societies and approximately 200 unregistered religious groups in the Slovak Republic; most of them are movements of Christian origin (Grešková 2013).

The surprising return of interest in religion was reflected in its destiny - with the globalization of the world grew the globalization of religion and the pursuit of dialogue, ecumenism, and interfaith dialogue on the one hand and the activity 
of religious radicalism on the other. While the former was either ignored or welcomed, the second led to a reaction in a global society that vehemently rejected forms of religious radicalism and fundamentalism; this was reflected not only in the structures of society but also in everyday interpersonal relationships. As a result of the radicalism of religion, a sense of threat naturally grew in society, evoking old stereotypes and creating new forms of intolerance; Stereotyping has become a tool for labelling, difference' and contributes to the world view in two opposing terms daily - on the one hand, we are ,we' and, on the other hand, ,they'. The subject of both attitudes is the question of , what does ' and ,what is' the second group as opposed to ,what is doing' and ,what is' our group. Within this view, even in the university's environment, it is possible to perceive the diversity of young children of character or their interests and values and habits that can be the target of ridicule or condemnation. According to Plichtová and Podolinská, the duality of the view ,we' - ,they' carries with it its own (usually negative) emotion and the current behaviour that follows from this view; in stereotypes and prejudices, according to the author, there is a present tendency to harm or cause discrimination (RTVS 2017).

Similarly, Pickering states that ,difference' is constructed as a deviation from normal, safe, or important. The definition of otherness is made consciously, i.e., to sensure the unification of the collective identity and separate the privileged from the subordinate (Pickering 2001, 49). Cipro agrees with this, referring to the tendency of the ,superiority complex' as an objective undesirable and dangerous moment, which aims at the social exclusion of underestimated minority groups and individuals within the social group (Cipro 2001).

The school space - the classroom - is also one of many social groups. There is stress from exams and the fear of failure, but these unpleasant feelings last forever after college, and we realize that our college life has brought us many lovely memories. These are pleasant and full of experiences for most graduates. However, some such students come to mind when they have to immerse themselves in books and scripts and face ridicule and paganism. The reason could be simplified, exaggerated, constantly recurring, and easily recognizable ,truths' with a negative emotional charge, as Burton and Jirák or any describe stereotypes ,difference' that was not accepted by the majority. Such a ,difference' is also the individual's religiosity (Burton and Jirák 2003, 196-197). One of the many definitions of religiosity speaks of it as a kind of belief in the existence of supernatural phenomena and beings, but the term religiosity already includes participation in activities that are directly related to this belief and its experience; according to experts, it is a complex of phenomena such as religious beliefs, experiences, and actions (Sekot 1985; Ševčíková 2004; Kuberová and Baňasová, 2015 and others). Briefly, religiosity describes how religion is realized within individual social groups and how one ,experiences' religion, i.e. to what extent his experience of religion affects his ordinary life, actions, decisions or understanding of duties, responsibilities for oneself and others, and so on; we consider interesting several different concepts of the role of humanity in the 
world which is represented by Vymetalová et al. (2020). Religiosity, in this sense, thus represents an observable manifestation of religion, which can be observed in a particular group of people over time and judged in various ways by an individual or another group of people. The paper will evaluate the religious manifestations of religious individuals from the perspective of the non-religious majority. We will evaluate the forms of stereotyping of non-religious students towards their religious classmates.

The term stereotype refers to a highly stable belief, almost independent of people's experiences. The stereotype represents the initial classification of phenomena and people, categorizing them into groups and, consequently, assigns positive and negative values to the given phenomena and people. Stereotypes are relatively stable patterns that persist even when their new findings do not confirm or even refute them. The stereotype can also be positive, which can no longer be said of a deliberately harmful prejudice, and is negative for subjective reasons, not for objective conditions (e.g., lack of information, note) (Burton and Jirák 2003, 196-197). Prejudice can also be aptly described through its anglicism; in the past, the term meant the English term prejudge, i.e., condemn in advance.

Several experts describe stereotypes and prejudices as similar concepts, and we also come across opinions where the two concepts are in a kind of conditioned relationship. According to social psychology, stereotypes relate to prejudices, but it is not the same. According to the experts, prejudices often begin as an expression of ethnocentrism, i.e., as we suggest above in the text, we judge others by the eyes of our group, and we consider that to be the best (AlIport 1954; Šišková 1998; Vašečka 2013, and others). Hinton pointed out an exciting phenomenon: positive self-presentation and identification with one's group do not automatically create negative stereotypes about, different' groups. The determining attribute is the ,type of foreign group' (Hinton 2000). In the study, we are interested in representing this ,foreign group' for the researched university students of the humanities and what reasons the students give for judging (and not once condemning) their classmates from the ranks of Jews, Christians, and Muslims.

As a starting point in thinking about stereotyping, we draw attention to the research conclusions by the Slovak Centre for Research on Ethnicity and Culture, which has long drawn attention to the deepening of ethnic tensions in society, discrimination against minorities, and intolerance of Slovaks to otherness. Despite the high social importance of religion, which is inherent in most Slovaks, there is tension in the relationship of the majority to any , difference'. According to experts, the reason for the tension is mainly the long-term debate, which portrays minorities in Slovakia as a threat and a real threat to the territorial integrity, cultural sovereignty, and dominance of the majority nation, which are ethnic Slovaks (Centrum pre výskum etnicity a kultúry 2019). 


\section{Methodology and review of the related literature}

The research presented in this study consisted of a combination of qualitative pre-research using a focus group and a qualitative-quantitative questionnaire completed by 140 university students. The chosen qualitative method of pre-research proved to be suitable, as the selected seven respondents were able to justify their statements in more detail or confront them with the opinions of other participants (see Table 1). The method was also valuable for identifying assumptions about stereotypes, verified in the quantitative part of the research, where the questionnaire was used. The focus group ended with a joint expression of the participants' agreement with the conclusions of the interview, which eventually eliminated potentially misinterpretations of the pre-research.

\begin{tabular}{|c|c|c|}
\hline \multicolumn{2}{|c|}{ Number of members: 7} \\
\hline Sex: & 4 men & 3 women \\
\hline Education: & $\begin{array}{c}2 \text { high school, } \\
2 \text { university }\end{array}$ & $\begin{array}{c}2 \text { high school, } \\
2 \text { university }\end{array}$ \\
\hline The religious point of view: & $\begin{array}{c}2 \text { believers, } \\
2 \text { unbelievers }\end{array}$ & 1 believer, 2 unbelievers \\
\hline
\end{tabular}

Table 1: Characteristics of focus group members. Source: own research.

The focus group was followed by research using a questionnaire method. The research aimed to identify decisive stereotypes in the research sample of (non-religious) respondents towards their religious classmates. The questionnaire was a combination of quantitative and qualitative questions and was designed to enable the acquisition of data and data on deeper reflection processes of the research sample (Gavora 2007). Although more challenging to categorize and interpret, we chose the path of seven open-ended questions. Our goal was not to present any variants of answers to the respondents. The method was a benefit, as we obtained many attitudes and exciting ideas from the respondents, which suitably complete the researched issues. There were 140 questionnaires; we categorized more than 980 answers. The other three questions of the questionnaire were closed. They either gave respondents the option to choose one of the options or asked the respondent to rank them according to preferences (i.e., on a scale of 1-5). The questionnaire was distributed to university students of humanities at the University of Žilina.

The two separate and time-phased parts of the research had different goals, used different research methods, and obtained their data, thus contributing to the main goal of the study, which was to research the decisive stereotypes of (non-religious) university students against their religious classmates, i.e., against Jews (1st partial objective), Christians (2nd partial objective) and Muslims (3rd partial objective). An overview of the research design is shown in Chart 2. 


\begin{tabular}{|c|c|}
\hline \multicolumn{2}{|c|}{ Research questions } \\
\hline $1^{\text {st }}$ research question: & What are the most common stereotypes of college students against Jews? (Q1) \\
\hline $2^{\text {nd }}$ research question: & What are the most common stereotypes of college students against Christians? (Q2) \\
\hline $3^{\text {rd }}$ research question: & What are the most common stereotypes of college students against Muslims? (Q3) \\
\hline 4th research question: & What are the desirable measures to prevent stereotyping in higher education? (Q4) \\
\hline \multicolumn{2}{|c|}{ Research methods } \\
\hline $\begin{array}{c}\text { Qualitative group interview } \\
\text { Qualitative-quantitative } \\
\text { questionnaire }\end{array}$ & 7 members of the group discussed 2 times for 2 hours \\
\hline
\end{tabular}

Table 2: Research design - Qualitative-quantitative research: research questions and research methods. Review of the related literature.

The issue of stereotyping Jews, Christians, and Muslims is extensive. That is why we choose a qualitative selection of historical and current events based on the available literature and the richness of historical and current studies on this issue. The aim is to approach the current reality and describe and analyse manifestations of stereotyping against Jews, Christians, and Muslims in Slovakia, yet in wider Europe. The choice of presented circumstances is conditioned by the real impact of these events on the present. We consider the optics of processing the issue to be essential - we notice members of religious minorities in Slovakia (i.e. Jews, Christians and Muslims) as ,victims of violence', not as ,actors of violence', as they are currently mainly Muslims, followed by Christians and Jews, as actors of violence have been the subject of many publications and comprehensive studies (Spencer 2006; Sartori 2005; Müller 2005; Mendel 2000; McGoldrick 2007; Küng and Van Ess 1998; Kropáček 1996; Kepel 2006; Fletcher 2003; Barša 2001; Anderson 1990, etc.).

The Stephen Roth Institute, an academic institution at Tel Aviv University, has long focused on studying anti-Semitism in Europe, presenting data on contemporary anti-Semitism and racism in Eastern Europe, including Slovakia. In addition to violence and vandalism, the institute also monitors the area of propaganda that interests us primarily due to the paper's topic. Data from the Institute speak of anti-Jewish literature (e. g., the Protocols of the Sages of Zion) and publications (denying the Holocaust, attempts to rehabilitate racist and fascist figures, etc.), stereotypical newspaper attacks, as well as targeted propaganda in the media or on the Internet. Attacks on Israelis in Eastern Europe also take place through election campaigns, ,street art' (the so-called graffiti) or leaflets with stereotypical arguments (e.g., Jews as actors in vandalism on Christian heritage, etc.) (The Stephen Roth Institute on Antisemitism and Racism [n.d.]).

Modern anti-Semitism identifies Jews, according to Vago, as the early spreaders of globalization and as its primary users. Stereotyping presents the picture that, with globalization, Jews are concerned about the global interests of the United States, world Jewry, and Israel; they are presented as aggressive forces, destabilizing the economy and society of European nations to dominate the world (Vago 2000). According to Jelínek, stereotypical accusations of Jews of espionage, 
betrayal, or unfair practices, favouring Israel' are common (Jelínek 2000). Thanks to globalization, the stereotypical image of a Jew in the eyes of Gentiles acquires other unflattering characteristics - in the words of Vago, he is "an eternally cunning Jew who has no roots and serves his interests spread all over the world" (Vago 2000, 26). Moreover, Jews always take a picture of the rich and influential, while others suffer misery. According to Jelínek, this view is based on another stereotypical belief, namely that "Jews manipulate facts or falsify them in order to suck out poor Eastern European states « (Jelínek 2000, 156-158).

Vago also points to the stereotypical ways in which Jews' claims for restitution and compensation are presented to the public in the countries of post-Christian Eastern Europe. The author aims to point out the stereotypical image of Jews who »extract money from post-communist states « (Vago 2000, 22). According to Vago or Králik, there is also a negative view of Jews because of the reasons for the Holocaust presented in society (Vago 2006; Králik 2020) As a result, right-wing extremists have been clearly and gradually negating the Holocaust since 1989. Their efforts are to raise minimal doubts about what happened to the Jews, casting a grey shadow on the struggle for historical memory.

In Slovakia, several experts map the issue of the relationship of the Slovak majority to the Jewish minority. Hradská points to the Jewish community as the first oppressed and shouted minority, which experienced economic prosperity in the 19th century, and eventually became a ,scapegoat' responsible for all the ills and problems of Slovak society at the time. According to Hradská, the word ,Jew' was identified among Slovaks in the 19th century (and beyond) with the word, usurer'. The tendency to look at Jews through the prism of their property position in society prevailed; negative passions were aroused by the economic power of the Jews and their economic expansion (Hradská 2014). Even according to Rybářová, Jews were given the adjective ,bearers of social injustice' among Slovaks, as Slovaks were in poverty, while "Jews always had large supplies" (Rybářová 2014). Jelínek recalls that it was even a period when he shouts, "Away with the Jews! Death to the Jews! (Jelínek 1999, 24).

The stereotyping of Jews in Slovakia in the first half of the 20th century was also helped by the belief that Jews reported Slovaks and sympathized with Hungarians. According to Krekovičová and Panczová, the Jews' efforts to »be a support for the Hungarian political, cultural and economic elites" contributed to this stereotype, making them »the enemy of Slovak nationalism « (Krekovičová and Panczová 2013, 35). According to Hradská, Jews in Slovakia were described as an organic part of Hungarian Jewry and bearers of Hungarianization - the enemy of the Slovak government and the nation (2014). Meštan pointed out that the accusation of Jews participating in the Hungarianization of Slovaks is also related to the current persistence of anti-Jewish nationalist and racial stereotypes. Finally, propaganda played an important role in the attitude of Slovaks towards Jews, proclaiming the question of whether »do Jews really have a Slovak national feeling? « Experience has shown that they lived in Slovakia as foreigners, linguistically, economically, and religiously (Meštan 2000a). The answer to the question was no. 
That is also why, as Hradská points out, the image of a Jew has always been the same - a Jew was "a usurer, a merchant, a robber, a muggle, a speculator, an exploiter« (Hradská 2004)

According to Meštan, the assimilation policy of the forty-year-old communist regime also supported racial stereotypes concerning minorities in the thinking of part of the population in Slovakia (Meštan 2000a). After the fall of the communist regime in 1989, some anti-Semitic phenomena revived, which were studied by Fatranová. According to the author, three phenomena appeared briefly and marginally after 1989: hatred towards Jews because Slovaks believed in the worldruling intentions of Jews; the opinion that Jewish Jews are robbing and robbing and accusing Jews of participating in the Hungarizaion of Slovaks. Fatranová thinks that only one phenomenon persists to this day - it is political clericalism. This case has become an echo of the effort to recognize the existence of Slovak statehood (Fatranová 2000). Mikloško also explains this more broadly when he points out that Tiso's execution after the war is still a Slovak trauma. "He was a priest, and hanging a priest is a disgraceful death that touches people deeply." This made him a martyr, so» the idea of Slovak statehood spread further in his execution « (Vagovič 2012).

In the 21st century, several groups of right-wing radicals (connected to the international network of extremist movements), which are characterized by negationism, revisionism, the Auschwitz lie, and other phenomena directed against Jews or questioning Holocaust crimes, began to activate in the approach to Jews in Slovak conditions. According to K. Hradská, establishing such movements in Slovak society is based on the demand for racial purity, often accompanied by anti-religious attitudes. It is a targeted promotion of intolerance and open anti-Semitism, which calls Judaism, heretical Hebrewism' and Jews, antichrists and liars'. At the same time, the Jews are credited with efforts for world domination and the goals of world mixing of races or the destruction of true Christianity. Vago currently associates the stereotyping of Jews in Slovakia with the nature and deeds of extremist movements. The author talks about the so-called ,Purifying history', i.e., twisting the past, which is backed by extremists' belief that the fate of the Jews during war-torn Slovakia was no different from the fate of ordinary Slovaks. According to the author, a new and current form of anti-Semitism is a systematic attack on the historical memory of the Holocaust to relativize the Holocaust (Vago 2000, 18-21).

In the study, we further approach the forms of stereotyping of Christians in Europe by secular society. The stereotyping of Christians is manifested primarily by attacks in the social sphere. The current reminder of exemplary cases can be found in the so-called $A$ shadow report on intolerance and discrimination against Christians in Europe. The text confirms the stigmatization of contemporary European Christianity as well as the day stereotyping of Christians. The report talks about marginalization, restrictions on freedom, and the social exclusion of Christians (which lead to a denial of Christian rights). According to several experts, at least four areas can be identified that are directly related to the problem of soci- 
al exclusion of Christians in contemporary Europe: (1) Exclusion of Christians from public life (e.g., non-acceptance of Christian views in the public sphere); (2) Creating stereotypes and prejudices against Christians based on their media image; (3) Focusing on the removal of Christian symbols (e.g., Christmas symbols); (4) Aggressive opposition to Christians in public positions. (Katolícka cirkev na Slovensku [n.d.])

Christians in Slovakia, according to members of the focus group, do not experience (or only rarely experience) the exclusion of religious groups from public life and space (as we see in other Europe) or religious persecution (as we see in the world), which does not mean that they do not perceive the whole several other forms of stereotyping due to religious intolerance. We mean, for example, condemnation for public and social expressions of faith (or refusal to understand faith only as a matter of individual conscience), derogatory stereotypes, attacks on the Church and total slander of Christians, aggressive secularism in the media, ridicule Christian ethical norms and values (i.e. issues of ethics, human life, family, marriage, sexuality), etc. According to the focus group, the sources of conflicts between Christians and other societies are also becoming ,secular', i.e., power or economic interests of Christian churches.

Carlin also speaks of the ,historical tricks' and ,outrage over evil' committed by Christians in society so far. According to the author, this is one of the fundamental reasons for the intolerance of Christians in today's society, which does not forget the crimes committed by Christians over the last two thousand years and remembers the violence brought to society by the Crusades, the Spanish Inquisition, the index of forbidden books, the court with Galileo or Copernicus, burning of witches, Catholic-Protestant religious wars and finally the current sex scandals within the church (Carlin 2019). The focus group members also consider Nietzsche's still surviving view of weak Christianity as a reason for stereotyping Christians today (Nietzsche 1995, 9).

Another of the conclusions adopted in the focus group recalls the much ridicule from the backwardness faced by the Christian churches in Slovakia. According to group members, the church is associated with regression primarily to defend tradition; low capacity to reform and adapt to the ,new age"; due to a conservative attitude towards homosexuals, homosexual partnerships, adoptions, and bioethics issues (e. g., artificial insemination) and due to the church's inability to accept a scientific shift. The conclusions of the focus group also suggest that the Christian church and believing Christians will be referred to as ,hypocrites'. The precondition of the focus group is also the opinion that young respondents can perceive the Christian faith as a ,kind of mental disorder', event. Christians can be considered irrational to stupid.'

Muslims are the second-largest religious and cultural community in today's multicultural Europe. The attitude of the post-Christian world towards Muslims is greatly influenced historically. Let us recall that the current phenomenon and attitude are preceded by the 20th century, when the colonial empires collapsed, in which Islam 
prevailed until then. In most Muslim countries, secular political regimes and Westernbacked governments have gained power. The penetration of ,oppression' prompted the emergence of more, from moderate to radical movements; in the West, these movements are often referred to as ,fundamentalist'. Even in Eastern Europe, especially after the fall of Communism, sthe militant Islam became the new ideological antagonist, feared for its anti-democratic elements and propensity to violence " Kardis et al. 2019, 113). The economic, cultural, or political influence of post-Christian countries manifested itself in the Muslim world in the 20th century under the pressure of unwanted modernization; a parallel phenomenon was the decline of Islamic communities. The reciprocal relationship between Islam and the post-Christian West divides the fatal view of Islam into Western civilization, the ,moral split' which Muslims interpret because of materialistic and immoral Western culture. At the same time, Islam presents itself as a bearer of correct values and true faith.

The reaction of Europeans shows that the religious intolerance of Muslims in Europe is gaining strength and emotion in the 21st century. This is confirmed, among other things, by the findings of the Eurobarometer from the end of 2015. These suggest that Muslims feel the lowest level of social acceptance among religious groups living in today's Europe (Európska komisia 2015). The subject of the current stereotyping of Muslims is their immigration to Western countries; it is followed in particular by economic problems (e. g. growing poverty and social disparities) and demographic problems (e. g. declining birth rates in European countries and rising birth rates among Muslims); however, there is also more and more talk about Europe's moral problems (significantly the increase in the antisocial behaviour of immigrants).

According to Bedford, the ,phobia of Islam' began in Europe, but still in 1989, when the British writer of Indian origin, Salman Rushdie, published his novel Satanic Verses in London. The book provoked a wave of unrest and protest demonstrations by Muslims; they demanded a death sentence for the novel's author. The domestic or Western media, which have begun to portray Islamists as dangerous and threatening individuals close to terrorism and extremism, have not contributed to the overall unsatisfactory situation (Bedford 1999). In this context, another fact that has an impact on the present turns out to be true. The third monotheistic religion becomes more tolerant when it feels powerful and selfconfident, and vice versa, when retreating from its positions of power, a message more intolerant. According to experts, 1 within themselves, they consolidate the fundamentalist currents which see the way out of difficulties as a return to the oldest rules" (Tonková 2007; Huntington 1996; Hykisch 2001; Laqueur 2006; Steyn 2006; Reeber 2006 and others).

In Slovakia, the Muslim community is small (approximately 5,000 people), and according to Čikeš, most Muslims represent a group of educated, employed people with a solid economic background (2020). The social status of Slovak Muslims differs significantly from the status of Muslims, for example, in Germany, the United Kingdom, France, or another European country. Especially in the media, however, there is a homogeneous stereotyping of ,European Muslims', which does 
not consider the diversity of nations, social statuses, and social roles. A small number of Muslims in Slovakia, yet a large media presentation of the problems associated with Islam, are also the subject of research that points to the hazardous consequences of Europeans' mediated experience with Muslims. We also see in this one of the reasons for the stereotyping of Muslims living in Slovakia. Finally, Slovak Muslims also reflected the situation, who perceive most of society as highly stereotypical (Dugovič 2015).

Semi-annual ethnographic research of Muslim migrants living in Bratislava is certainly interesting in the researched issue. It is a study of the attitude of Slovaks to Islam by Cenker, who states that in connection with Muslims in Slovakia, there is an vargument that is often distorted, simplified and rejected" (Cenker 2010, 223). The author brings a study with a detailed description of the experiences of the religious life of Muslims in our capital. Bratislava Muslims openly talk about the great degree of adaptation to the environment, i.e., the Slovak world in which they move. According to the conclusions of this research, the inadaptability of Slovak Muslims seems to be a stereotype. Finally, valuable research from the environment of Charles University in Prague testifies to the negative attitude of Slovaks towards Islam. Its authors Polonský and Novotný examined whether knowledge of Islam influenced anti-Islamic prejudices and confirmed by research that the higher the level of knowledge, the more prejudices we hold against Muslims; the more our fear of Islam grows in our territory (Novotný 2001). The research concludes that respondents are most concerned about Islamic terrorism and the growing problems of the growing integration of Muslims.

\section{Results}

Results of the study bring several findings that can be divided into three levels according to three research questions:

In a preliminary survey dealing with the existence of stereotypes against Jews in a seven-member focus group and a survey of stereotypes against Jews in a research sample of 140 respondents, we noted a relatively rare agreement - in both cases defining the five most common stereotypes about Jews in the context of Slovak culture. Our findings are shown in Figure 1.

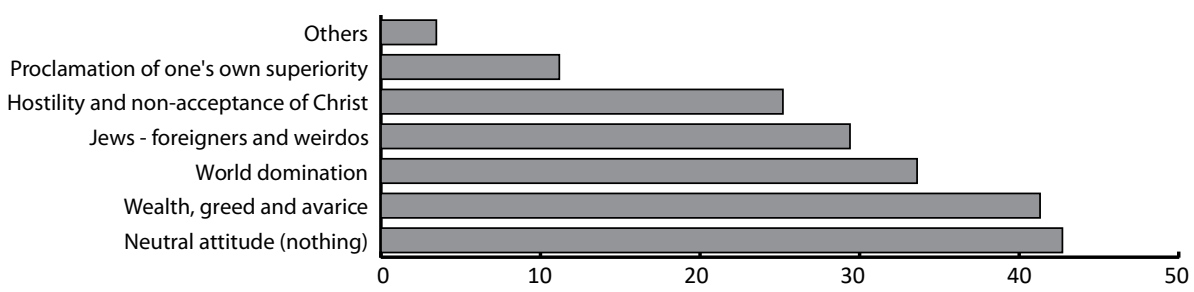

Figure 1: The most common stereotypes among university students against Jews. Source: own research. 
Figure 2 shows our findings, i.e., the description of the focus group members of presumed stereotypes towards Christians and the findings - stereotyping of Christians in respondents. Five central stereotypes about Christians were identified in the pre-research and the questionnaire. Among the university students whose opinions we obtained through the questionnaire, there were two stereotypes that the focus group members did not anticipate: the respondents' opinion of the intolerance and condemnation of others from Christians and an opinion that reflects the backwardness of Christianity.

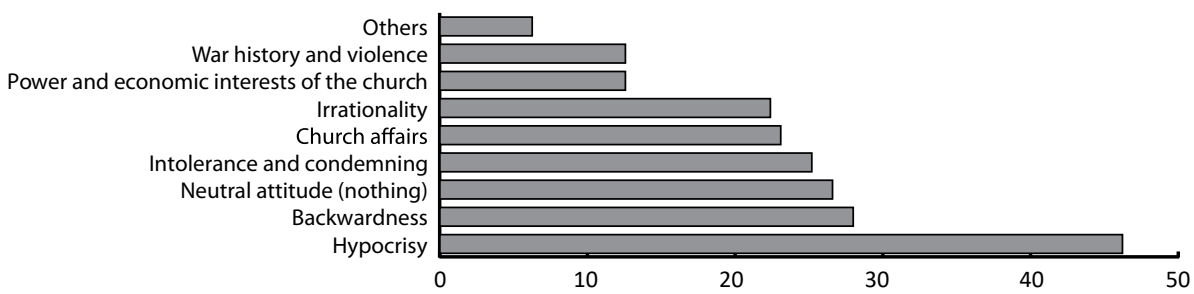

Figure 2: * Stereotypes from the questionnaire that the members of the focus group did not anticipate

The most common stereotypes among university students against Christians. Source: own research.

The opinions and attitudes of 140 Slovak university students in quantitative research revealed the most common reasons for the religious intolerance of young Slovaks towards Muslims. Based on the findings, we state that all five assumptions of the focus group members were confirmed. In addition, the focus group members did not anticipate the other two stereotypes, which found themselves to a relatively significant extent in the respondents' statements in the questionnaires. The first stereotype or prejudice was the respondents' belief that Muslims lead an , unattractive' way of life. The second statement from the respondents is that Muslims are for most Europeans (and Slovaks) ,unwanted neighbours'. According to the questionnaire respondents, "they are not able to participate in life in Western countries". Our findings are shown in Figure 3.

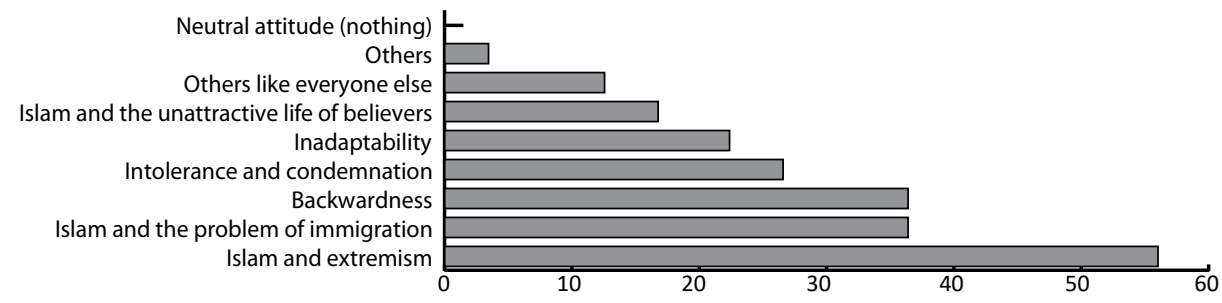

Figure 3: * Stereotypes from the questionnaire that the members of the focus group did not anticipate

The most common stereotypes among university students against Muslims Source: own research. 


\section{Discussion}

\subsection{1st partial objective - Stereotyping of Jews}

To the question "what hinders you the most about Jews? (Which aimed to reveal the forms of stereotyping of respondents towards Jews), respondents answer as follows: In the questionnaire, the first three most common answers were »nothing, I do not know, and I did not meet with a Jew «. The results suggest a certain indifference in the evaluation of Jews. However, it cannot be ruled out that these three most common answers are interdependent - the lack of personal experience may mean that I do not find any mistakes in a person (i.e.,»nothing bothers me«) and that the question »I do not know to respond«.

After the highest values assigned to the neutral answers, the assumption of a stereotype about the wealth, greed, and avarice of the Jews was confirmed. Behind this is the belief that the business abilities of Jews are always accompanied by the ,affection' of Jews for usury and fraud in the business. Based on these stereotypes, Jews are considered those who love wealth. At the same time, they are ,greedy and avaricious', because from what they give to others from what they own, i.e., do not share and are ,greedy', i.e., they desire to own more than they need in life. The assumption of the focus group on this stereotype was confirmed in the research sample in both its meanings, i.e. a Jew as a miserly man and a Jew as a greedy man. The number of opinions gave this stereotype the second-highest value of $41.3 \%$.

The questionnaire also includes a stereotypical view of a Jew as a ,foreigner' in the sense of ,weirdo' (29.4\%). Respondents also give examples of different and not exactly understood Jewish customs and laws governing eating, celebrating holidays, or circumcision of young children. The appearance of the Jews is also evaluated negatively: "braids", , "bad hygiene", "they are ugly", "I do not like their appearance", "they look unsympathetic, " and so on. Respondents also confirm some antipathy towards Jewish culture and especially religion: »I do not know what bothers me, but we all know that Jews have always belonged to the group of less popular ones"; "Their customs and traditions are strange"; "They have always been different "; "My religious way of life hinders me«; "They do not try to resolve their relations with the Arabs« and so on.

In the questionnaire, the argument that Jews oppose Christianity, possibly against Christ, was $25.2 \%$, thus confirming the assumption from the focus group in the pre-research. K. Hradská, for example, also perceives this attitude as a danger. She recalls the anti-Jewish attitudes presented in connection with Christianity in groups of right-wing radicals, known for calling Jews , antichrists' and ,liars', attributing to them, among other things, efforts to destroy true Christianity (Hradská 2007, 174). We record the answer that the Jews are "guilty of the crucifixion of Christ " only in the amount of $4.9 \%$. The longest surviving anti-Semitic phenomenon - the belief that the Jewish people are to blame for the crucifixion of the Son of God seems to weaken. Hradská similarly states this, evaluating this as a positive 
consequence of the church's efforts for interfaith dialogue and cooperation with followers of other religions (Hradská 2007). In the context of our findings, we believe that this stereotype helps to alleviate, among other things, the efforts of Christian churches to return to the Jewish roots of their faith.

The so-called ,the superiority of the Jews' is a stereotype that hinders $11.2 \%$ of respondents. According to members of the focus group, »ewish ethnocentrism (perceived as superiority) is associated with several other stereotypes of Jews in our country /.../ and evokes hatred, which has serious social consequences". The focus group members talk about the consequences, such as conflicting social conditions, unsatisfactory coexistence of the majority and minority, violence against individuals on the streets, vandalism, and the destruction of cultural heritage. Negative references in the context of preferring the importance of Israelis can also be seen in the replies to the questionnaire; for example, there are claims that Jews are "guys with orthodox faith and a belief that they are chosen «; "They are picky and consider themselves superior to others"; "They promote their faith as the sole and only true truth and then rise above others"; »It prevents me from acting - they look conceited« and so on.

The assumption that the respondents will stereotypically perceive Jews in the form of images "New as a tavern, usurer or impostor " was not confirmed (the assumption was presented in a study by K. Hradská 2014; J. Alner 2011 and others) - mention of "Jew the innkeeper " or "usurer " does not even appear at all in the answers as well as mention of "Jew as a traitor", an event "collaborator with the Hungarians « (the assumption was presented in a study by P. Meštan 2000a; G. Fatranová 2000; K. Hradská 2014; E. Krekovičová and Z. Panczová, 2013 and others). Let us recall that the given stereotype is based on the idea of a Jew - innkeeper and is based on the belief that Jewish innkeepers reported Slovaks and sympathized with the Hungarians by arousing hatred towards the Slovak government and the nation (Hradská 2014). Thirdly, we add that the questionnaire does not include a stereotype, which, according to Fatranová or Vago, persists in Slovakia - it is political clericalism (possibly the so-called ,The Tiso case') (Fatranová 2000; Vago 2000). On the positive side, the surveyed university students show no signs of attempting to relativize the Holocaust, as stated by Vago, nor do they mention the stereotypical view of Jews' intentions to achieve world race mixing or the destruction of Christianity referred to by Hradská (Vago 2000; Hradská 2007).

\subsection{2nd partial objective - Stereotyping of Christians}

We are aware of the tension between Christian teaching and the practical implementation of this teaching in the lives of believers through the observations of the members of the focus group and the findings of the questionnaire. The stereotype of Christians - hypocrites was confirmed among the young people in our research sample to the highest extent (46.2\%). Respondents refer to Christians primarily as ,hypocrites'; fewer common descriptions of Christians are ,saints'; "superficial people who hide behind incense» alike. According to respondents, 
Christians are ,pretending'; "They choose from faith only what is right for them "; "They behave in the opposite way to their faith "; "They preach to others what they should do and do not do it themselves "; "They do not behave like true Christians"; "They judge a man by going to church and behaving worse than he is "; "They pretend to be believers, but they go to church only to be seen by other people", and so on. We believe that in this case, we can talk more about ,prejudices', as these are negative attitudes of respondents, resulting from their subjective reasons (Burton and Jirák 2003, 196-197).

The focus group members did not assume that the respondents would associate Christianity, i.e., Christian churches and Christians with ,backwardness'. According to the respondents, the church is associated with regression mainly for the defence of traditions; low capacity to reform and adapt to the ,new age; due to a conservative attitude towards homosexuals, homosexual partnerships, adoptions, and bioethics issues (e. g. artificial insemination) and due to the church's inability to accept a scientific shift. The stereotype of ,church backsliding' continues in the questionnaires, mostly with accusations that the church is also,evil' because it denies a person everything nice and pleasant and forces him, in the respondent's words, ,to follow the rules or live in constant renunciation'. The ridicule of the backsliding of Christians is again followed by a stereotypical ,sarcasm' against basic Christian values. From the respondents' point of view, Christians are especially reproached for being »backsliding as their faith « and »blindly following the orders of their church and following tradition«.

The same surprise that the focus group members did not anticipate was the stereotype of Christians as ,intolerant and alienating other people'. Therefore, it is an interesting phenomenon, where the young generation expresses its opinion on what they see in their surroundings and does not perceive it positively. The opinion that "Christians are intolerant and alienate others " was stated in the questionnaire by $25.2 \%$ of respondents, which is the third most common answer. The statements in the questionnaire do point to the pressure to ,accept the Christian worldview' that respondents perceive from the Christians they meet. This is evidenced, for example, by the respondent's opinion: "Religions in themselves are not a problem. The problem is extremism in faith. It is weird, but I feel, at home' - with our Christians".

The media presentation of church cases and affairs also significantly contributes to the increase in negativism towards Christianity and the church and to prejudices (possibly stereotyping; for example, paedophilia and sex scandals, politicization and radicalism of the views of church leaders, presentation of ,efforts' to cover-up scandals in the church, etc.). The conclusions of our research, in which the assumption of the focus group was also confirmed in the questionnaire, also point to criticism of the church for the given reasons; we recorded $23.1 \%$. Let us add that, in connection with the cases in the questionnaires. There are also allegations in which a significant part of the research set is openly separated from the church and states that "the church is a corrupt power "; that »one can believe in God, but one cannot trust the church«, or that »one can believe in God without 
the church .

A stereotypical view of the, irrationality' of Christians in our research sample was confirmed in $22.4 \%$ of respondents (e. g., sexual intercourse after marriage, baptism of young children, decency, faith in the effect of prayer, etc.). We will also mention the more extensive statements from the questionnaire: »He who believes in some salvation must be a fool - we will all end up in the dust «; »/t is a senseless belief in something that may not even exist"; "One has many shortcomings; it should be clear to them (Christians) that the saint was no one and believes in delusion « and so on. In the context of this stereotype, Christians are referred to in the questionnaire as ,blind faith heretics'; ,naïve'; ,prudish biblists', ,flocks of sheep' and ,mentally ill people'. The statement confirms, among other things, the finding presented in the empirical part of the work that in most countries of contemporary Europe, persecution of Christians has various forms of hatred, and Christians face them daily. This is largely related to Christian stereotypes, as it is stereotyping according to Sedlák that begins the process of »using derogatory names to describe groups considered " different "and continues to justify such reworked, prejudiced and judged differences, and symbolic distance (Sedlák 2008 , 201). According to Allport, the stereotype in this process often justifies and justifies mostly negative attitudes and behaviours. (Alport 1954, 191). Let us add that Nietzsche's well-known claim about the ,death of God' does not appear in the respondents.

In their statements, the respondents also show negativity towards the church, which they also associate with the ,secular' interests of the church, i.e., the assumption of focus group members that the respondents of the questionnaire will be hindered by "power and economic interests of the church « was confirmed. The variable was mentioned by $12.6 \%$ of respondents. Questionnaires also include a negative reference to the Christian historical heritage in the questionnaires, i.e., violent and military interventions, in the name of the faith'. The group members assumed the stereotype in the preliminary research and were confirmed by $12.6 \%$ of the respondents in the questionnaire. Interestingly, respondents needed to comment on the negative past of Christianity as a reason for their unbelief.

In the context of qualitative statements from the questionnaires, it can be seen that the respondents' attitude towards Christians includes not only the application of stereotypes but also the relatively frequent application of prejudices, which are harmful for subjective reasons. Our research group contributes to negativity towards Christians by encouraging individuals to view and innocently evaluate other people. However, it is an evaluation in opposite terms - on one side there are ,we' (i.e. ,normal' people) and on the other side they are ,they' (i.e. ,radical', ,fanatical', ,irrational', ,hypocritical' and similar Christians). In connection with the evaluation of Christians, we also find in the answer's elements of negative thinking, especially cynicism, simplification, underestimation, prejudices, belief in conspiracy theories, and pessimism. In addition, a unique phenomenon is taking place among the respondents - the positive qualities are interpreted as negative in Christianity. We mention, for example, the statement: »Christians are too polite«; 
"They do not swear... «; "They see everything positively and thank God for everything (even for evil) «; or the opinion, "I am bored by the decency of Christians, it is not normal«. Although reverence, a positive perception of life circumstances, or decency are generally positive qualities, in the context of our findings, they surprisingly appear as ,criticism', that is, negative feedback; The good news is that, according to experts, criticism helps us name the conflict so that, if there is a will, we can clarify things and look for constructive solutions to problems and misunderstandings (University of Cambridge 2017).

\subsection{3rd partial objective - Stereotyping of Muslims}

Muslims set a goal to unite the world in one good faith, that is, Islam. For this purpose, Muslims have, jihad' (i.e. effort, activity, possibly spreading the faith). According to the focus group members, this fact is well known in our society, and therefore the stereotype, all Muslims are extremists' is well established in Slovakia. The assumption of the research group was confirmed. More than half of respondents (56\%) considered Muslims as extremists; throughout the survey, only this variable received an overwhelming majority of responses. From the answers to the questionnaire, the most common are ,reproach of Islamic terrorism ' and ,condemnation of suicide attacks'. Third, the respondents also refer to the fanaticism of Muslims in practising the faith as extremism. In this context, our research findings also raise the doubts of respondents about the ,meaning of faith', education and ethics of Muslims or ,the value of Muslim culture and religion'.

Another stereotype contains a reproach of the inability to integrate Muslims in Western countries. This is an opinion that the research group members did not anticipate; that is, it came out of the questionnaire, and we recorded it in $36.4 \%$ of respondents. We see that the presence of Muslims in Europe is of concern to respondents, and perhaps the fear of over-immigration may be understood. The indicated problems provoke reactions - among other things; we see the stereotyping of all Muslims without distinction and the generalization of media references that speak of the inability of the integration of Muslims in Western countries; According to several experts, including Weigl and Tkáčová, the current Muslim minority in the West is passing through the so-called identification crisis. It is a perception of one's non-acceptance by the majority society, which is often accompanied by a feeling of uprooting and strong exclusivity (often even discrimination) by the majority (Weigl 2006, 31-37; Tkáčová 2014, 79).

The focus group members expressed the assumption that a stereotype about ,backwardness of Islam' may appear in the questionnaire. This has to do with the relationship of religious individuals to the ,scriptures' of Muslims. Also, in Christianity, for example, the New Testament has a central place in the core of the concept of Christianity (Martin et al. 2020). However, as the intervention of the Qur'an and Sunnah in the case of Islam is visible in all areas of the lives of contemporary Muslim believers (although »life had changed significantly since the 7 th century when Islam originated «, as members of the focus group recall), there are currently controversial, contradictory formulations or concepts with different 
interpretations. In post-Christian Europe, we see arguments »that total exclusion of religious beliefs for example from public debate is wrong ", but the same arguments clearly "refuse extreme exclusivism and defend moderate exclusivism « (Žalec and Pavlíková 2019, 75). The assumption from the preliminary research was also confirmed in the questionnaire. The problem of the backwardness of Islam, mainly due to the exclusivity of the Qur'an and Sunnah, is perceived by up to $36.4 \%$ of respondents, which is the second most common answer. From our research findings, the respondents understand two areas as a manifestation of the backwardness of Islam' are more pronounced. The first is the understanding of the position of women in Islam based on the Qur'an and Sharia. The second thing is the Muslim belief that the Qur'an is God's constant and unchanging revelation (Hadith 1:3 verses 55-57). Opinions on the backwardness of Islam, together with respondents' belief in the inability to integrate Muslims in Western countries, were the second most common statements made by respondents in the questionnaire.

The focus group members also assume an opinion of Muslims, which will point to their ,intolerance and condemning' in the research sample. The seven-member team had in mind the moral judgments that result from the Qur'an and form the basis for the alienating attitude of believing Muslims toward ,unbelievers' that is, to the rest of the non-Muslim world. Sharia also proves to be problematic. "Muslims in the Qur'an is always orthodox and unharmed, Christians on the contrary«, says the participants in the preliminary research. We find similar statements in the questionnaire, so we state that the assumption about this stereotype was confirmed and was the third most common variable for young respondents with a value of $26.6 \%$.

Members of the research group refer to Muslims in European countries as " unadaptable and intolerant«. Their assumption that the questionnaire respondents will similarly evaluate Muslims was confirmed; the variable acquired a value of $22.4 \%$. The following statements of the respondents evidence the existence of the stereotype in our research sample: "Muslims lead a barbaric way of life, in contrast to our civilized «; »They impose their faith and way of life on others, which I consider intolerant «; "They are not sympathetic because they hate Christians"; We cannot see that ,inadaptability and intolerance' are attributed to Muslims primarily in the matter of religion, that is, concerning other believers. This finding is shared by prominent experts such as S. Huntington, professor B. Tibi, Islam specialist professor G. Kepel and, in part, American political scientist B. Barber. They agree that contradictions and conflicts occur mainly between groups with different religions, as religion is their main distinguishing feature (Huntington 1996; Tibi 1995; Kepel 2006; Barber 1996).

The list of the most common stereotypes continues with the conviction of respondents about the ,unattractive life of believing Muslims'; $16.8 \%$ of respondents express this opinion through a questionnaire. All the examples that respondents describe as unattractive are significantly dominated by the obligation to cover women; it is a phenomenon that hinders almost half of respondents (49\%). Re- 
spondents do not comment on the ban on veiling women for religious reasons; they are aware, however, of the wider scope of this issue, in particular the ,fear of black clothing; "Discrimination and social distance of Muslim women from other people of Western culture« and »the problem of identifying Muslim women in publicu.

The stereotype of Muslims who , are different from everyone else' was confirmed in a questionnaire of $12.6 \%$. This finding confirms that in the case of stereotyping in religious intolerance, it determines the degree of positivism and negativism concerning believers, according to Hinton, to a large extent »the type of foreign group « (Hinton 2000, 49). In the case of Muslims, it is a group that Slovaks perceive as ,the most distant'. This attitude is reinforced not only by religion but also by customary, cultural differences, the relationship between politics and religion, the significant participation of religion in the private life of Muslims, and the like in the evaluation of Muslims as ,other' and ,different', respondents rely mainly on the recent experience of violent manifestations (beliefs) of Muslims in European countries (historical conflicts are mentioned minimally, note). The result is a verbalized feeling of aversion and open hostility, which can be observed in most questionnaires. Respondents' statements about the ,difference' of Muslims from the majority of Slovaks, possibly Europeans, can be uniformly described through the statement of one of the respondents - „Muslims are different from us; they are the greatest foreigners for us".

Finally, respondents to the question »what bothers me about Muslims« never once used the opportunity to answer with »l do not know« or »l did not meet a Muslim «. However, this possibility is highly probable in Slovakia (due to the small number of Muslims). Even more interesting is that the respondents did not once say that they did not mind, nothing' about Muslims. The neutral attitude (nothing, I do not know, I did not meet), which was most common in the case of Jews (42.7\%) and also in the case of Christians (26.6\%), does not appear in the results of the research into the (non) existence of stereotyping of Muslims ( $0 \%$ ).

\subsection{4th partial objective - The desirable measures to prevent stereotyping in higher education}

To meet the fourth partial objective, we finally consider current measures in stereotyping young Jews, Christians, and Muslims in the environment of universities in Slovakia. Due to the complexity and the number of areas covered by the topic, we avoid formulating final recommendations in the following section. Instead, we will focus on proposals that could be supportive, as they emerged from the theoretical and methodological background of this study, reflect the values and inclinations of the authors of this study, and rely on the conclusions of the just presented pre-research and research:

Strengthening respect for diversity and variety in the university environment: Reducing the stereotyping of religious students determines their social inclusion and leads to strengthening respect for diversity and variety. Educational activities 
can lead to a greater degree of respect for different cultural, social, or ethnic ,differences', to increasing sensitivity to respect and protection of minorities as well as the identity of religious individuals; to increase students' knowledge and skills in the field of human rights and intercultural dialogue and the like.

Support for initiatives aimed at the complete elimination of manifestations of stereotyping: The university environment represents a suitable space for the implementation of activities whose primary and secondary goal is the elimination of stereotyping, xenophobia, racism, and ethnic intolerance. A parallel phenomenon of these initiatives may be steps leading to strengthening social communication channels that improve the quality of intercultural discourse, increase intercultural awareness, and eliminate prejudices and stereotypes in the university environment.

Solving the emotional level of the problem and non-acceptance: Solving the emotional level of the consequences of stereotyping also proves necessary. The perception of one's non-acceptance, feelings of uprooting, and exclusivity on others pushes religious young people out of university youth's social life events. It thus robs them of an essential element of the so-called quality of life. The feeling of non-acceptance, uprooting, and non-participation is, among other things, responsible for the phenomenon of social exclusion, and this, among other things, again influences the growth of stereotyping. It is a targeted creation of initiatives, which are also an excellent alternative to the shared experience of ,difference', which students have so far perceived mainly through the media. As Petrová and Nemec remind us, decades ago, the first theories on the impact of digital technologies have started to appear. First, television and later computers were criticized by humans, such as their learning or reading (Petrová and Nemec 2019). Today we cannot doubt especially the negative impact of the media. Therefore, the support for initiatives aimed at the complete elimination of manifestations of stereotyping is even more welcome and necessary.

Active participation of religious students in social inclusion: For successful inclusion (especially Jews and Muslims), it is necessary to get these students to improve the quality and effectiveness of developed initiatives and programs. The participation of religious students is necessary, encouraged, and welcomed by program proponents, mediators, faculty leaders or their assistants, teachers, volunteers, etc. Active participation will undoubtedly contribute to greater inclusion of religious students or the development of their ,local identity', i.e., "An expression of belonging to a locality and a local society« (Králik et al. 2018, 69).

Linking religious students with local authorities: Linking individuals with local authorities within a particular university could be an appropriate measure in the social inclusion of religious young people (possible members of religious minorities); we mean authorities such as educators, educational counsellors, school social workers, heads of departments or faculties, and others. These people are important local actors in the university environment and can be available to a member of a minority if needed. In this sense, we consider their coordinated co- 
operation as one of the possible solutions, as a rich network of experts and their competencies can contribute to solving potential problems through their own professional social and educational activities in the university environment (even outside the university) to the higher motivation to resolve conflicts, to lower stereotyping in the collective and ultimately to more secure social inclusion of religious students in the university environment.

Targeted programs for students as part of the school's educational policy: Exclusive programs focused on stereotyping in society give the impression that Jews and Muslims in particular (as ,different' ones) need a unique approach, and relief leads to the opposite result. Special attention to activities and projects is sometimes needed. However, if possible, especially the participation of religious students - Jews and Muslims - in these programs should not be exclusive (the so-called special programs and policies), but on the contrary, incorporated into programs designed for all (with sensitive inclusion and addressing the specific needs of members of religious minorities). The measure can act as the putty in the local community, helping to reduce tensions and break down stereotypes and prejudices.

\section{Conclusion}

We are sure that impartial research on the actual or potential motivation of stereotyping among young people in Slovakia can be helpful not only in the context of social exclusion of religious students but also in solving many problems in the context of discrimination and marginalization. This was also one of the motivations for stereotyping research; today, we can talk about the significance or benefits of this study. We wanted to gain a deeper understanding of the causes that lead individuals, consciously or unconsciously, to stereotypical intolerant attitudes toward other people.

The task of the focus group within the pre-research was to determine the forms of stereotyping towards Jews, Christians, and Muslims in Slovakia. To identify and describe the forms of stereotyping in religious students at a selected university in the Slovak Republic, we verified the assumptions from the preliminary research in 140 university respondents through a questionnaire. The research will carry out the fact that Jewish anti-Semitism is universal, has remorse for Jewish social, historical, and religious ethnocentrism, contains stereotypical accusations, and stretches throughout the history of Slovaks. It seems that a new trend of anti-Jewish attitude is emerging in Slovakia - in short, Jewish anti-Semitism is, in addition to the traditionally religious character, increasingly secular, i.e., racially and ethnically oriented.

Stereotypes about Christians have also persisted among Slovaks for decades. The existence of religious wars significantly influences the attitude of believers towards their religion (i.e., Christianity), violent re-Catholicization, declarations 
and behaviour of the Catholic priest and president of the fascist republic J. Tis in the pre-war period, anti-church communist propaganda, or scandalous image of Christian churches (mainly in tabloid) media.

According to Grešková, distrust of religious institutions (we see it especially concerning traditional churches) is domesticated in Slovak society with the curiosity of some and the suspicion of others (Grešková 2013). The stereotypes found against Christians in the university environment illustrate that stereotyping manifests itself in ways beyond the usual expression of , disagreement'. It is increasingly taking the form of verbal oppression, ridicule, and paganism, which are encouraged, among other things, by a stereotypical view of the ,difference ${ }^{\prime}$ in the life of the church and its devotees.

Based on mediated cases with elements of religious intolerance and stereotyping towards Christians, we state, together with members of the research group, that the existence of anti-Christian stereotypes in contemporary Europe and Slovakia conditions many other phenomena: »Reinforcing existing prejudices, offering negative media images of Christians, slander and defamation, which often creates social hostility and professional hardship, or the frequent misuse of art to desecrate Christianity«. Christians face »the suppression or removal of religious symbols, the marginalization of Christian ideas and individuals in the context of political correctness and the rules of political discourse". Also common are "vandalism, the desecration of Christian buildings, and hate crimes against individuals because of their convictions".

Probably Muslims have the worst picture among Slovaks. According to the research group from our preliminary research, the causes of stereotyping against Muslims in Europe and Slovakia are the loss of peaceful content of Islam, the rise of Islamization, and the fact that violence against Muslims in Europe is a response to ,fanatic' violence. Other significant problems (more or less based on stereotypical views) include the vague differences between the ,political' and, religious' motives of believers; regrets of the inability of Muslims to integrate into Western countries; conviction of obscurantism (event. backwardness) in Islam; moral judgments, which represent the alienating attitude of believing Muslims towards ,infidels'; respondents' beliefs about the inadaptability and intolerance of Muslims in European countries; the perception of life based on Islam as an unattractive life and the view that Muslims are different from us, that is, "they are the greatest foreigners to us". For these reasons, Muslims in European countries, including Slovakia, may perceive that their religion is increasingly perceived as a radical religious system without the possibility of change; a parallel phenomenon is the undeniable stereotyping of Muslims, both in the media and in ordinary streets.

Among other things, this is confirmed by the final question of the questionnaire, in which we asked about the definition of religious intolerance. Most respondents formulated their answers in relation to Islam and Muslims. Among the three groups examined in our research, we believe that Muslims face the highest level of intolerance in the context of qualitative findings from pre-research. More- 
over, we do not find the hateful attitude and stereotyping of respondents only connected with radical Muslims. Once again, the respondents' opinions represent the belief that ,our' is better, more correct, more attractive and, above all, more civilized. In short, the stereotypical view of Muslims is, due to the differences in this culture and religion, relatively visible among the young Slovaks studied.

We can state that the objectives of the paper were met. The study presents an overview of relevant research in stereotyping of Jews, Christians, and Muslims and subsequently the own research findings - the forms and consequences of stereotyping religious young people in higher education.

We see the importance of research in a set of established and subsequently verified assumptions about stereotypes against Jews, Christians, and Muslims in the research group, i.e., among young people in adolescence, which according to experts, is a period of significant holistic personality formation, i.e., accepting or rejecting the opinions of others, including opinion orientation on the, difference of others'. The design and verification of the usefulness of the research methodology also consider as a contribution of the research.

The research shows the acute need to implement prevention measures that would positively reduce the stereotyping of religious students in higher education. Reducing stereotypes and prejudices can have, among other things, a significant impact on enhancing diversity and variety in the higher education environment, increasing students' knowledge and skills in cultural diversity and human rights, and, finally, the social inclusion of religious young people, their quality of higher education and education and, ultimately, their future.

\section{References}

Allport, Gordon W. 1954. The Nature of Prejudice. Cambridge, MA: The Beacon Press. Archive. com. https://archive.org/stream/in.ernet. dli.2015.188638/2015.188638.The-Nature-Of-Prejudice_djvu.txt (accessed 19. 9. 2020).

Anderson, Norman. 1990. Islam in the Modern World: A Christian Perspective. Leicester: Apollos.

Barber, Barber. 1996. Jihad vs. McWorld: Terrorism's Challenge to Democracy. New York: Ballantine Books.

Barša, Pavel. 2001. Západ a islamizmus: Střet civilizací, nebo dialog kultur? Brno: Centrum pro studium demokracie a kultury.

Bedfordová, Carmel. 1999. Prípad Rushdie: Osm let zápasu za svobodu projevu. Prague: Mladá fronta.

Burton, Graeme, and Jan Jirák. 2003. Úvod do studia médií. Brno: Barrister \& Principal.

Carlin, David. 2019. 15 dôvodov pre ateizmus v dnešnom svete. Denník Postoj, 3. 8. https:// svetkrestanstva.postoj.sk/45847/15-dovodov- pre-ateizmus-v-dnesnom-svete (accessed 19. 9. 2020)

Cenker, Michal. 2010. Moslimskí migranti v Bratislave. Sociológia 42, no. 3:213-236.

Centrum pre výskum etnicity a kultúry. 2019. Aktuálne projekty. CVEK. http://www.cvek.sk/main. php?p=projekty\&lang=sk (accessed 19. 9. 2020).

Cipro, Miroslav, and Jaroslav Balvín, eds. 2001. Romové a sociálni pedagogika. Ústí nad Labem: Hnutí R.

Čikeš, Radovan. 2020. Islam v Európskej únii. Rozmer. http://www.rozmer.sk/sk/articles/ print/428 (accessed 19. 9. 2020).

Dugovič, Matej. 2015. Slovenského moslima sa zákazník pýta: Ste terorista? Denník 18. 1. https://dennikn.sk/24751/slovenskeho-moslima-sa-zakaznik-opytal-ci-je-terorista/ (accessed 19. 9. 2020)

Európska komisia. 2015. Otázky a odpovede týkajúce sa prvého každoročného kolokvia o základných právach v EÚ: predchádzanie a boj 
proti nenávisti voči židom a moslimom v Európe. European Union, 1. 10. https://ec.europa.eu/commission/presscorner/detail/sk/ MEMO_15_5739 (accessed 19. 10. 2020).

Fatranová, Gila. 2000. Životnost' antisemitských javov. In: Meštan 2000b, 161-176.

Fletcher, Richard. 2003. Křiž a pulměsíc. Prague: Mladá fronta.

Gavora, Peter. 2007. Sprievodca metodológiou kvalitativneho výskumu. Bratislava: Univerzita Komenského v Bratislave.

Grešková, Lucie, and Ondrej Prostredník, eds. 2013. Cudzie nechceme, svoje si nedáme?: Prekonávanie xenofóbie a antisemitizmu v náboženských textoch a praxi. Bratislava: Univerzita Komenského v Bratislave.

Hadíth 1. [n.d.]. Chapter 4, verses 55-57. Hadith Collection, http://hadithcollection.com/ (accessed 19. 9. 2020).

Hinton, Perry. R. 2000. Stereotypes, Cognition and Culture: Psychology Focus. Philadelphia: Routledge.

Hradská, Katarina, in Eduard Nižňanský, eds. 2007. Z dejín holokaustu a jeho popierania. Bratislava: Stimul.

Hradská, Katarina. 2014. Vzt́ah majority k židovskej menšine (nielen) v 19. storočí. Officiálna stránka katolíckej cirkvi na Slovensku. https:// www.kbs.sk/obsah/sekcia/h/dokumenty-a-vyhlasenia/p/zborniky-z-konferencii/c/bratislava-konferencia-kczi2014-06 (accessed 19. 9. 2020).

Huntington, Samuel. 1996. The Clash of Civilizations and the Remaking of World Order. New York: Touchstone.

Jelínek, Yeshayahu A. 1999. Židia na Slovensku v 19. a 20. storoči: Zborník statí I. čast'. Bratislava: Múzeum židovskej kultúry.

- - - 2000. Antisemitizmus v postkomunistiskej východnej Európe a štát Izrael III: Antisemitizmus v politickom vývoji Slovenska. In: Meštan 2000b, 156-158.

Kardis, Maria, Peter Sturak, Roman Králik, Daneila Nguyen Trong, Andrey V. Korzhuev and Nina I. Kryukova. 2019. A sociological-religious probe into contemporary global salafi jihadism. European Journal of Science and Theology 15 , no. 4:113-125.

Katolícka cirkev na Slovensku. [n.d.]. Ostatné dokumenty: Tieňová správa o netolerancii a diskriminácii voči krest́anom v Európe (20052010). Officiálna stránka katolíckej cirkvi na Slovensku. https://www.kbs.sk/obsah/ sekcia/h/dokumenty-a-vyhlasenia/p/ostatne-dokumenty/c/ccee-tienova-sprava-o-netolerancii-a-diskriminacii-voci-krestanom-v-europe (accessed 19. 9. 2020).
Kepel, Gilles. 1996. Boži pomsta: Křest'ané, židé, muslimové znovu dobývají svět. Prague: Atlantis.

- - . 2006. Válka v srdci islámu. Prague: Karolinum.

Králik, Roman, Ladislav Lenovský and Martina Pavlíková. 2018. A Few Comments on Identity and Culture of One Ethnic Minority in Central Europe. European Journal of Science and Theology 14, no. 6:63-76.

Králik, Roman. 2020. Justice and Memory-Story about Eichmann and Argentina. European Journal of Science and Theology 16, no. 4:1-3.

Krekovičová, Eva, and Zuzana Panczová. 2013. Obraz nepriatel'a v počiatkoch slovenskej politickej karikatúry: Vizuálne stereotypy v časopise Černokňažník v rokoch 1861-1910. Slovenský národopis 61, no. 1:31-33.

Kropáček, Luboš. 1996. Islamský fundamentalizmus. Prague: Vyšehrad.

Kuberová, Helena, and Anna Baňasová. 2015. Krestáanská spiritualita pre liečebných pedagógov a iných v pomáhajúcich profesiách. Ružomberok: Verbum.

Küng, Hans, and Joseph Van Ess. 1998. Křestánství a islám. Prague: Vyšehrad.

Martin, José García, Dinara G. Vasbieva, Josef Polacko and Hedviga Tkacova. 2020. Kierkegaard's Point of View on Luther in His Journals. XLinguae 13, no. 3:31-39.

McGoldrick, Dominik. 2007. Human Rights and Religion: the Islamic Headscarf Debate in Europe. Oxford: Hart.

Mendel, Miloš. 2000. Náboženství v boji o Palestinu: judaismus, islám a křestáanství jako ideologie etnického konfliktu. Brno: Atlantis.

Meštan, Pavel. 2000a. Niektoré špecifické podmienky reprodukcie negatívneho stereotypu Žida na Slovensku po roku 1989. In: Mešt́an 2000b, 177-190.

Meštan, Pavel, ed. 2000b. Acta Judaica Slovaca, no. 6. Bratislava: Múzeum židovskej kultúry.

Müller, Zdeněk. 2005. Svaté války a civilizační tolerance. Prague: Academia.

Nietzsche, Friedrich W. 1995. Tak pravil Zarathustra. Olomouc: Votobia.

Petrová, Zuzana, and Ratislav Nemec. 2019. Changing Reading Paths in a Digital Age: What are the Consequences for Meaning-Making? Journal of pedagogy, no. 2:65-85. https://doi. org/10.2478/jped-2019-0007

Pickering, Michael. 2001. Stereotyping: The Politics of Representation. Basingstoke: Palgrave.

Polonský, Filip, and Josef Novotný. 2011. The Level of Knowledge about Islam and Perception of Islam among Czech and Slovak University 
Students: Does Ignorance Determine Subjective Attitudes? Sociológia 43, no. 6:674-696.

RTVS. 2017. Veda SK. RTVS. https://www.rtvs.sk/ radio/archiv/11373/631407 (accessed 19. 9. 2020).

Rybářová, Petra. 2014. Antisemitizmus v Uhorsku v 80. rokoch 19. storočia. Cited by Katarina Hradská, Vzt́ah majority k židovskej menšine (nielen) v 19. storočí. Officiálna stránka katolíckej cirkvi na Slovensku. https://www.kbs. sk/obsah/sekcia/h/dokumenty-a-vyhlasenia/p/ zborniky-z-konferencii/c/bratislava-konferencia-kczi2014-06 (accessed 19. 9. 2020).

Sartori, Giovanni. 2005. Pluralismus, multikulturalismus a pristěhovalci. Prague: Dokořán.

Sedláková, Renáta. 2008. Obraz Seniorů a Stáŕí v Českých Médiích Aneb Přispívají Mediální Obsahy k Vytváření Věkové Inkluzivní Společnosti? In: Michal Bočák and Juraj Rusnák, eds. Médiá a text. Vol. 2, 198-210. Prešov: Filozofická fakulta Prešovskej university.

Sekot, Aleš. 1985. Sociologie náboženství. Prague: Svoboda.

Ševčíková, Stanislava. 2004. Stupně víry ve vývoji člověka. Dialog Evropa XXI. 14, no. 1-4:108120.

Šišková, Tatjana, ed. 1998. Výchova k toleranci a proti rasismu: sborník. Prague: Portál.

Spencer, Robert. 2006. Islám bez závoje: Zneklidňující otázky o nejrychleji rostoucím náboženství. Prague: Triton.

Štatistický úrad slovenskej republiky. [n.d.]. Sčítanie obyvatel'stva SR v r. 2001, 1991, 2011. Štatistický úrad slovenskej republiky. http:// portal.statistics.sk/files/tab-15.pdf (accessed 19. 9. 2020).

The Stephen Roth Institute on Antisemitism and Racism. [n.d.]. Annual Reports on Worldwide Tendencies and Developments in Antisemitism: General Analysis for the Year 2016, 2017, 2018. The Stephen Roth Institute on Antisemitism and Racism. https://en-humanities.tau. ac.il/roth/publications/gen (accessed 19. 9. 2020).
Tibi, Bassam. 1995. Krieg der Zivilisationen: Politik und Religion zwischen Vernunft und Fundamentalismus. Hamburg: Hoffmann und Campe.

Tkáčová, Hedviga. 2014. Podoby koexistencie krestáanstva a islamu v pluralitnej západnej spoločnosti. Teologický časopis 12, no. 1:57-81.

Tonková, M. 2007. Historické premeny islamu: Islam vo svetových dejinách. Vojenská osveta 2:2-29.

University of Cambridge. 2017. Behavioural Attributes Framework. Cambridge University. https://www.hr.admin.cam.ac.uk/policies-procedures/behavioural-attributes/behaviouralattributes-framework (acessed 19. 9. 2020).

Vago, Raphael. 2000. Antisemitizmus a politika v postkomunistickej strednej a východnej Európe. In: Mešt́an 2000b, 18-27.

Vagovič, Marek. 2012. Deklarácia svedomia. Týždeň. https://www.tyzden.sk/casopis/12075/deklaracia-svedomia/ (accessed 19. 9. 2020).

Vymetalová Hrabaková, Eva, Peter Kondrla, Vera K. Vlasova, Svetlana V. Dmitrichenkova and Olga V. Pashanova. 2020. Human as the Protector of Creation. XLinguae 13, no. 3:13-21. https://doi.org/10.18355/XL.2020.13.03.02

Weigl, Jiří. 2006. Viníkem je spíš evropský sociální stat. In: Benjamin Kuras, ed. Islám v Evropě obohacení, nebo nebezpečí?, 31-37. Prague: Centrum pro ekonomiku a politiku.

Wohlrab-Sahr, M. [n.d.]. In the Shadow of the Return of Religion. University of Leipzig. https://www.sozphil.uni-leipzig.de/cm/kuwi/ files/2014/02/RM-MWS-engl.pdf (accessed 19. 9. 2020).

Žalec, Bojan, and Martina Pavlíková. 2019. Civic Virtues and Functions of Religion in Public life. European Journal of Science and Theology 15, no. $6: 75-84$. 